The article presents the result of determining the effectiveness of normative legal regulation of the right to freedom of creativity. It is established that the criteria of effectiveness are: a) the perfection of legal regulation of the right to freedom of creativity; b) conformity of normative legal acts in the sphere of the right to freedom of creativity with socio-economic and political realities, possibilities of exercising the norms of the right of creative competences enshrined therein and their protection in court; c) reduction of imperative, imperative methods of regulation by increasing the dispositive methods; d) a clear definition of the types of legal responsibility for the violation of the right to freedom of creativity. As a result of the theoretical modeling of the evaluation of the effectiveness of the normative legal regulation of the right to creativity in Ukraine, it is proposed to amend the legislation.

It is proved that Article 54 of the Constitution of Ukraine should be set out in the following wording: types of intellectual activity. Everyone is guaranteed the right to the results of his intellectual, creative activity; no one may use or distribute them without his or her consent, except as provided by law. The state contributes to the development of all kinds of creative activity, establishing appropriate ties of Ukraine with the world community. Cultural heritage is protected by law. The state ensures the preservation of historical monuments and other objects of cultural value, takes measures to return to Ukraine cultural values of the people who are beyond its borders.

It is substantiated that these changes will enhance the effectiveness of ensuring the right to freedom of creativity in terms of creating a scientifically sound system of legislation and its ability to ensure that the real needs and interests of the subjects of law are harmonized.

The inconsistency of normative legal acts in the sphere of the right to freedom of creativity with socio-economic and political realities has been proved. There is a lack of effective socio-economic support for creators, creative unions and associations. It is substantiated that tendencies of socio-economic development should be directed to the development of science, technology, and culture.

It is noted that the absence of a definition of the concept of academic responsibility in the legislation testifies to the lack of a clear definition of the types of legal responsibility for violations in the field of the right to creative work. creativity.

Key words: right to freedom of creativity, effectiveness of legal regulation, freedom of literary, artistic, scientific and technical

DOI: $10.36695 / 2219-5521.1 .2020 .11$

Удк ЄС $340.132(477: 4-€ С)$

\title{
О.С. ПЕРЕДЕРІЙ
}

Олександр Сераійович Передерій, кандидат юридичних наук, доцент, доцент Харківського національного університету імені В.Н. Каразіна*

ORCID: 0000-0003-4898-876X

\section{ТЕНДЕНЦІЇ ТРАНСФОРМАЦІЇ ЗАКОНОДАВЧИХ ЗАСАД ЄВРОПЕЙСЬКОЇ IНТЕГРАЦІЇ УКРАЇНИ НА СУЧАСНОМУ ЕТАПІ}

Постановка проблеми. Після проголошення незалежності України у 1991 р. розпочинається етап активного налагодження політико-правових та інших зв'язків між нею як пострадянською державою і Європейським Союзом (далі - СС). Заінтересованість України у поглибленні політичних і економічних зв'язків 3 державами Західної Європи, яка мала місце на початку 1990-х рр., існує й сьогодні, адже формування сучасної вітчизняної ринкової економіки вимагає впровадження нових технологій, інтеграції у світову економіку, пошук ринків збуту для українських виробників, забезпечення присутності України у геополітичних процеcax ${ }^{1}$. Окрім реформування економіки, Україна розпочала співробітництво зі структурами СС у політико-правовій і гуманітарній сфері, що супроводжувалося змінами національного законодавства і впровадженням у національну практику державотворення правових стандартів СС щодо забезпечення прав людини, розвитку громадянського суспільства та гуманітарного сектору, лібералізації політичної системи тощо. Означені процеси стали основою політики європейської інтеграції України.

Починаючи з 1991 р. і до сьогодні в Україні було прийнято значну кількість актів законодавства, різних за юридичною силою і предметом правового регулювання, положення яких становлять юридичні засади реалізації євроінтеграційних прагнень нашої країни. Зокрема, це і двосторонні угоди з СС, які містили норми програмного характеру, Закони України, відомчі угоди органів центральної виконавчої влади України з окремими інституціями $€ \mathrm{C}$, підзаконні нормативні акти з окремих аспектів європейської інтеграції, акти відомчої нормотворчості тощо. Певною мірою зміст і регуляторний потенціал таких документів відповідав динаміці політичних відносин України, ЄС та інших держав на конкретний момент часу, що зумовило динаміку постійного оновлення і трансформації законодавчих засад європейської інтеграції України в останні роки.

Виділення невирішених раніше частин загальної проблеми, котрим присвячується стаття. 21 березня 2014 p. i 27 червня 2014 р. було підписано політичну i, відповідно, економічну частину Угоди про асоціацію між Україною, з однієї сторони, та Європейським Союзом, Свропейським співтовариством з атомної енергії і їхніми державами-членами (далі - Угода про асоціацію), з іншої сторони. Після ратифікації Угоди Верховною Радою України 16 вересня 2014 р. ії положення стали частиною національного законодавства держави і являли собою сучасну правову основу для євроінтеграції ${ }^{2}$ Після набрання чинності Угодою про асоціацію у новітній історії України спостерігається безпрецедентна динаміка оновлення і змін організаційно-правових основ європейської інтеграції. За таких умов формується практична необхідність визна-

(C) О.С. Передерій, 2020

* Oleksandr Perederii, Ph.D. in Law, Associate Professor, Associate Professor of V.N. Karazin Kharkiv National University 
чення закономірностей реформування національного законодавства з огляду на вимоги ЄС щодо впровадження загальноєвропейських стандартів організації державного управління, регулювання економічних i виробничих процесів та реформування гуманітарної сфери. Більш того, наукова розробка закономірностей трансформації правової основи євроінтеграційної політики України є запорукою оптимізації цих процесів 3 урахуванням соціально-правових, політичних і інших чинників.

Аналіз останніх досліджень і публікацій дає підстави констатувати, що аспекти правового забезпечення європейської інтеграції України потрапляли у центр наукової уваги багатьох дослідників у процесі дослідження означеної проблематики. Наукові положення, які було напрацьовано Л.І. Берендою, Л.І. Даниленком, В.С. Кириченком, А.Ю. Мартиновим, І.Ю. Матюшенком, І.В. Поліщуком, В.В. Резніковим, А.М. Шульгою, I. В. Яковюком, О.Н. Ярмишем, стали інформаційною базою для розробки обраної тематики статті. Водночас системне наукове обгрунтування спрямованості розвитку нормативної бази для реалізації Україною євроінтеграційних прагнень залишається недостатнім.

Беручи до уваги викладене вище, метою статті $є$ визначення основних тенденцій трансформації законодавчих засад європейської інтеграції України, які спостерігаються на сучасному етапі розвитку державності після укладення Угоди про асоціацію.

Виклад основного матеріалу. Укладення Угоди про асоціацію і набуття нею чинності було не лише значною політичною подією для держави, а й мало значні наслідки для правової системи України. Так, 3 юридичної точки зору після укладення Угоди про асоціацію спостерігається оновлення правової бази співробітництва України і ЄС, адже втратила чинність значна кількість актів договірного права, які раніше регламентували відносини двох сторін. Активна робота з пристосування положень Угоди про асоціацію до національної практики державотворення зумовила оновлення законодавчих засад європейської інтеграції. Комплексно підходячи до аналізу тенденцій правотворчості у вказаному сегменті, є можливість об'єднати їх як існуючі і виокремити трансформаційні тенденції.

Ведучи мову про тенденції трансформації законодавчих засад європейської інтеграції, найбільш значущою для суспільства зміною у законодавстві стало доповнення чинної Конституціӥ Украӥни. Значущість основного закону у житті кожного суспільства важко недооцінити. Відповідно, модернізація конституції завжди пов'язана 3 докорінними змінами в будові суспільства, що закріплюються чи породжуються конституційними установленнями ${ }^{3}$ У національній практиці державного будівництва проєвропейський вектор розвитку легітимізувалися на рівні Конституції України лише на 27 рік державної незалежності. Після сплину чотирирічного терміну після укладення Угоди про асоціацію в Основному Законі України було офіційно закріплено орієнтацію зовнішньополітичного курсу на всебічне наближення до ЄС. Так, на початку 2018 р. за ініціативою Президента України було прийнято Закон України «Про внесення змін до Конституції України (щодо стратегічного курсу держави на набуття повноправного членства України в Свропейському Союзі та в Організації Північноатлантичного договору)» від 7 лютого 2018 р. № 2680-VIII (далі - Закон про зміну Конституції України) 4 . У результаті зазначених нововведень було доповнено преамбулу Конституції України, в якій визначено європейську ідентичність Українського народу і незворотність європейського курсу України. Це положення було внесено в конституційний текст у зв'язку з тим, що у преамбулі Угоди про асоціацію зазначено, що Україна, розвиваючи відносини з ЄС, проголошує свою європейську ідентичність і поділяє спільні цивілізаційні цінності.

Окрім викладеного вище, було розширено коло повноважень Верховної Ради України і Президента України. Зокрема у новій редакції ст. 85 і ст. 102 Основного Закону визначено, що національний парламент повноважний реалізовувати стратегічний курс держави на набуття повноправного членства України в СС, а Президент України є гарантом реалізації цього курсу. У ст. 116 Основного Закону Кабінету Міністрів ставиться завдання забезпечувати реалізацію стратегічного курсу держави на набуття повноправного членства України в Європейському Союзі.

Конституційні зміни є одними з найбільш важливих політико-правових передмов для трансформації не лише системи національного законодавства, а й усієї правової системи держави. Це пояснюється кількома чинниками. По-перше, суб'єкти правотворчості всіх рівнів у процесі розробки і прийняття нормативних актів зобов' язані враховувати зазначені вище конституційні положення про обов'язковість євроінтеграційного курсу держави. Це є передумовою до збільшення кількості нормативних засад реалізації євроінтеграційного поступу. По-друге, це буде сприяти розвитку більш тісних політичних, економічних і гуманітарних відносин України з європейським співтовариством. У свою чергу, намагання сторін максимально розвинути такі стосунки дає як Україні, так і ЄС низку безцінних переваг. Найбільш важливою 3 них, як справедливо зазначає I.В. Яковюк, є накопичення «безцінного і різнопланового» досвіду співробітництва, який слід конструктивно використати ${ }^{5}$. По-третє, поступова реалізація нових положень Конституції України безпосередньо відобразиться на політичній мобільності суспільства. У Пояснювальній записці до Закону про зміну Конституції України доцільність внесення «євроінтеграційних зміни» до тексту Основного Закону обгрунтовується тим, що зміни до Конституції України мають на меті мобілізувати «українське суспільство і українську владу та сприятимуть проведенню реформ, спрямованих на досягнення критеріїв повноправного членства в ЄС»6. Відповідно, це законодавче формулювання спонукає до незворотності таких «мобілізаційних» змін, які мають відбутися у свідомості широких верств суспільства. Невипадково сьогодні в українському суспільстві спостерігається зростання очікування від держави євроцентристських досягнень у сфері зовнішньої і внутрішньої політики, а також подальшого реформування національного права у напрямі імплементації європейських моделей суспільного регулювання. А.М. Шульга пояснює цей феномен впливом на свідомість людей «майбутніх норм права», які розраховані на регулювання суспільних відносин, які лише починають формуватися 7 . 
Так чи інакше, але введення на вищому законодавчому рівні імперативу про обов'язковість і незворотність євроінтеграційного курсу є, фактично, декларацією держави про запровадження на національному рівні апробованої у ЄС моделі цивілізаційного розвитку. Слушною у зазначеному контексті є точка зору Л.І. Даниленко та І.В. Поліщук, які пояснюють пріоритетність євроінтеграційного курсу України прагненням пристосуватися до сучасних умов глобалізації через модернізацію країни ${ }^{8}$. Дійсно, перспектива входження України до ЄС, незважаючи на певні ризики, відкриває для України багато нових можливостей в економічній, гуманітарній, геополітичній сферах. Юридичне забезпечення євроінтеграційних процесів є однією із первинних передумов успішної реалізації таких можливостей.

Наступною важливою тенденцією трансформації законодавчих засад європейської інтеграції України є оновлення документів, які регламентують плановість процесу імплементації положень Угоди про асоціацію у національну практику державотворення. Невдовзі після укладення Угоди про асоціацію, 17 вересня 2014 р., Кабінет Міністрів України вів у дію Розпорядження № 847-р. «Про імплементацію Угоди про асоціацію між Україною, з однієї сторони, та Європейським Союзом, Свропейським Співтовариством 3 атомної енергії і їхніми державами-членами, з іншої сторони» ${ }^{9}$. У документі було визначено План заходів 3 поетапної імплементації Угоди про асоціацію в національну практику державного будівництва до 2017 р. (далі - План). План містив 28 глав і 92 пункти, які передбачали комплекс організаційно-правових заходів, реалізація яких забезпечила б трансформацію правової, безпекової, економіко-виробничої, культурної та інших сфер. Важливим змістовним компонентом процесу імплементації Угоди про асоціацію було визначення відповідальних суб’єктів за реалізацію конкретних заходів плану. Виконання Розпорядження № 847-р. стало потужним імпульсом для активізації відомчої нормотворчості для реформування конкретних сфер управління. Органи центральної виконавчої влади почали активно розробляти і вводити у дію нормативні документи, які містили детальні моделі впровадження положень Угоди про асоціацію на галузевому рівні. Разом із тим, у зв'язку з мінливістю внутрішньоекономічних і зовнішньополітичних умов упродовж строку чинності документа, у 2014-2017 pр. його положення сім разів зазнавали суттєвих змін і доповнень. Більш того, наприкінці 2017 р. структури Європейського Союзу офіційно повідомили, що виконання Угоди про асоціацію в частині апроксимації законодавства відбувається повільно і з порушенням запланованих термінів ${ }^{10}$.

Пізніше, 25 жовтня 2017 р., План заходів 3 імплементації Угоди про асоціацію було оновлено і введено в дію постановою Кабінету Міністрів України № 1106 (далі - План заходів по імплементації) ${ }^{11}$. Оновлений План заходів порівняно з Розпорядженням 2014 р. - документ, набагато більший за обсягом, який містить 1943 пункти. Кожен конкретний пункт відповідає певній статті Угоди про асоціацію, а також визначає суб'єктів, що відповідальні за реалізацію заходів задля втілення в життя приписів цієї статті. Актуальним 3 огляду на змінення законодавчих основ європейської інтеграції є те, що План заходів 2017 р. передбачає внесення змін до широкого переліку законодавчих актів України, які регулюють відносини у різних сферах. Практика трирічної реалізації Плану заходів по імплементації вказує на те, що План зазнавав суттєвих змін і доповнень. У листопаді 2019 р. Кабінетом Міністрів України було значно доповнено документ новими положеннями, які передбачають додатковий комплекс заходів із кореляції змісту запланованих раніше кроків 3 імплементації Угоди про асоціацію та уточнення термінів виконання конкретних реформ ${ }^{12}$. Зокрема, було ухвалено 16 законопроєктів та постанов, які передбачають поглиблення співпраці з Свросоюзом, досягнення відповідності України критеріям членства в ЄС. Зміст таких доповнень значною мірою був зумовлений необхідністю надання нового політичного імпульсу темпам реформування системи національного законодавства відповідно до Угоди про асоціацію в багатьох напрямах. Зокрема, це митна і фінансова політика, оподаткування, підприємництво, фінансові послуги та конкуренція; юстиція, соціальні й гуманітарні питання; транспорт; енергетика та енергоефективність; цифрова сфера, наука, технології та інновації; природокористування 13 .

Ще однією стійкою тенденцією трансформації законодавчих засад європейської інтеграції України є внесення змін до чинної редакції Угоди про асоціацію. Формально, такі зміни вносяться шляхом прийняття Верховною Радою України Закону про зміни до Угоди про асоціацію. Але цьому передує узгодження таких змін у процесі засідань Ради асоціації, яка складається із членів Уряду України, членів Ради Європейського Союзу і членів Свропейської Комісії. Рішення Рада асоціації приймає за результатами контролю та моніторингу виконання сторонами Угоди про асоціацію. Такі рішення мають обов'язкову силу для України і ЄС та тягнуть за собою внесення змін у додатки Угоди про асоціацію з урахуванням розвитку права ЄС i особливостей організації різних сфер взаємодії сторін. Зокрема, одна із останніх змін торкнулася додатку XXVII Угоди про асоціацію, яким було переглянуто зобов'язання України та ЄС щодо проведення спільного оперативного моніторингу виконання директив і регламентів СС 3 енергетичної політики ${ }^{14}$. Доповнення додатку відкрило додаткові можливості рухатися до секторальної інтеграції серед тих пріоритетів, визначені сторонами Угоди про асоціацію.

Також з 2014 р. по 2020 р. розповсюдженою практикою стало зміна (заміна) протоколів та додатків до Угоди про асоціацію на рівні фахових органів співробітництва України і ЄС (Комітет Асоціації і підкомітети). Такі зміни мають організаційно-технічний характер і покликані оптимізувати співробітництво України $і$ структур ЄС з найголовніших питань, що мають обопільний інтерес. Більш того, СС безпосередньо заінтересований у тому, щоб положення Угоди вчасно модернізувалися у відповідь на реалії соціально-економічного і технічного прогресу. Це цілком відповідає ідеології розвитку двосторонніх відносин в інновативний спосіб, адже історичний досвід довів, що розширення Євросоюзу за рахунок країн Східної Свропи мало багато негативних наслідків для самого $\mathrm{CC}$, адже колишні держави радянського блоку певним чином гальмували науково-технічний розвиток через успадковані від планової системи організації господарювання особливості15. Поглиблення відносин ЄС з Україною, з їі численними застарілими рудиментами управління 
організацією виробничої і наукової сфери народного господарства, потенційно може стати чинником гальмування впровадження інновацій у всі сфери суспільного життя. На сьогодні, за офіційною інформацією, яку оприлюднено на сайті Верховної Ради України з 2014 р. по 2019 р. включно, було прийнято 12 міжнародних документів $з$ питань доповнення Додатків до Угоди про асоціацію і прийняття (зміни) протоколів 3 найбільш актуальних питань співробітництва. Зокрема, було розроблено п’ять Рішень Ради асоціації, три Рішення Комітету асоціації та чотири Рішення підкомітетів Комітету асоціації16. Така тенденція $є$ позитивною за своїм характером, адже свідчить про те, що Угода працює, а практика реалізації їі основних положень накопичується. У кінцевому підсумку це сприяє інноваційному розвитку правової системи України і модернізації нашої держави згідно із загальноєвропейськими стандартами.

До того ж слід зауважити, що на офіційному рівні оприлюднюється інформація про необхідність майбутніх ревізій Угоди про асоціацію з перспективою внесення до неї змін шляхом укладення нових угод. Так, за заявою віцепрем’єр-міністра України з питань європейської і євроатлантичної інтеграції Д. Кулеби оптимальним шляхом подальшої кореляції нормативних положень Угоди про асоціацію є підписання між Україною і СС нових угод і це дасть можливість «точково підходити до проблемних питань та їх вирішувати»17. Це дає підстави констатувати, що подальші зміни чинної Угоди про асоціацію неминучі. На початок 2020 р. очевидною є доцільність внесення змін до Угоди про асоціацію з багатьох аспектів політико-правового та економічного співробітництва.

Висновки і перспективи подалышої наукової розвідки у зазначеному напрямі. Беручи до уваги викладене вище, вважаємо, що існуючі на теперішній час тенденції розширення законодавчих засад європейської інтеграції України слід корегувати з огляду на систему глобальних, регіональних і внутрішньодержавних політичних і правових чинників. В основу системної роботи Верховної Ради України, Президента України і Кабінету Міністрів щодо подальшого удосконалення законодавчих засад європейської інтеграції має бути закладено два взаємопов'язаних концепти - оптимізація механізму реальної реалізації євроінтеграційних перетворень у практиці національного державного управління, а також підготовка законодавчого забезпечення подолання глобальних політичних ризиків і економічних загроз, які можуть мати місце у зв’язку 3 імплементацією Угоди про асоціацію. Особливо «відчутним» у зазначеному контексті має стати генерування ефективного законодавства 3 питань врегулювання інвестиційної привабливості України та гарантування правового захисту іноземних інвестицій, адаптація національного виробничого сектору України до вимог ЄС, гармонізація національної моделі правового регулювання ринку праці з ЄС, підвищення інституційної спрямованості органів влади України втілювати Директиви $\mathrm{CC}^{18}$. Відповідно, практично зумовленим завданням національної правової доктрини є вироблення наукових пропозицій щодо подальшого розвитку законодавчих засад європейської інтеграції України і модернізації національної правової системи відповідно до прогресивних вимог і стандартів СС.

${ }^{1}$ Мартинов А.Ю. Свропейська інтеграція. Енциклопедія історії України: / редкол.: В.А. Смолій (голова) та ін. / НАН України. Інститут історії України. Київ: В-во «Наукова думка», 2005. Т. 3: Е-Й. 672 с.: іл. URL: http://www.history.org.ua/?termin= Evropeyska_integraciya (дата звернення: 03.01.2020).

2 Про ратифікацію Угоди про асоціацію між Україною, з однієї сторони, та Свропейським Союзом, Свропейським співтовариством з атомної енергії і їхніми державами-членами, з іншої сторони : Закон України від 16 вересня 2014 р. № 1678-VII. Відомості Верховної Ради України. 2014. № 40. Ст. 2021.

3 Ярмиш О.Н., Кириченко В.С. Зовнішні чинники в конституційному будівництві. Вісник Національної академї̈ правових наук України. 2014. № 3. С. 97.

4 Про внесення змін до Конституції України (щодо стратегічного курсу держави на набуття повноправного членства України в Свропейському Союзі та в Організації Північноатлантичного договору) : Закон України від 07 лютого 2018 р. № 2680-VIII. Відомості Верховної Ради Украӥни. 2019. № 9. Ст. 50.

5 Яковюк І.В. Свропейський Союз і Україна: еволюція взаємовідносин. Вісник Академї правових наук України. 2009. № 3. C. $14-28$.

6 Пояснювальна записка до проєкту Закону України «Про внесення змін до Конституції України (щодо стратегічного курсу держави на набуття повноправного членства України в Європейському Союзі та в Організації Північноатлантичного договору)» / Офіційний вебпортал Верховної Ради України. URL: http://w1.c1.rada.gov.ua/pls/zweb2/webproc4_1?pf3511=64531 (дата звернення: 06.01.2020).

7 Шульга А.М. Загальнотеоретичні аспекти правомірної поведінки особи: монографія. Харків: Майдан, 2013. С. 147.

8 Даниленко Л.І., Поліщук І.В. Перспективи та виклики євроінтеграційних процесів для України : навч.-метод. матеріали. Київ : НАДУ, 2013. С. 5.

9 Про імплементацію Угоди про асоціацію між Україною, з однієї сторони, та Європейським Союзом, Свропейським Співтовариством з атомної енергії і їхніми державами-членами, з іншої сторони : розпорядження Кабінету Міністрів України від 17 вересня 2014 р. № 847-р. Офіиійний вісник Украӥни. 2014. № 77. Ст. 2197.

10 Акуленко Любов. Підсумки року: успіхи та провали у виконанні Угоди про асоціацію. Інтернет-сайт «Європейська правда». URL: https://www.eurointegration.com.ua/articles/2017/12/15/7075035/ (дата звернення: 05.01.2020).

11 Про виконання Угоди про асоціацію між Україною, з однієї сторони, та Європейським Союзом, Свропейським співтовариством з атомної енергії і їхніми державами-членами, з іншої сторони: постанова Кабінету Міністрів України від 25 жовтня 2017 р. № 1106. Офіційний вісник Украӥни. 2018. № 24. Ст. 852.

12 Про внесення змін до плану заходів з виконання Угоди про асоціацію між Україною, з однієї сторони, та Європейським Союзом, Свропейським співтовариством 3 атомної енергії і їхніми державами-членами, з іншої сторони : постанова Кабінету Міністрів України від 20 листопада 2019 р. № 1005. Офіційний вісник України. 2019. № 99. Ст. 3316

13 Уряд схвалив 16 законопроєктів та постанов для європейської інтеграції України : офіційне повідомлення Департаменту комунікацій Секретаріату Кабінету Міністрів України, опубліковано 20 листопада 2019 р. / Урядовий портал. Єдиний вебпортал органів виконавчої влади України URL: https://www.kmu.ov.ua/news/uryad-shvaliv-16-zakonoproektiv-ta-postanov-dlyayevropejskoyi-integraciyi-ukrayini (дата звернення: 08.01.2019). 
14 Про Рішення Ради асоціації між Україною та ЄС про внесення змін і доповнень до Додатка XXVII до Угоди про асоціацію між Україною, з однієї сторони, та Європейським Союзом, Свропейським співтовариством з атомної енергії і їхніми державами-членами, з іншої сторони : Закон України від 06 червня 2019 р. № 2739-VIII. Відомості Верховної Ради України. 2019. № 27. Ст. 112.

15 Яковюк І.В. Інноваційна стратегія ЄС: уроки для України. Право та інноваційне суспільство. 2014. № 2. С. 8.

16 Міжнародні документи (Рада асоціації між Україною та Європейським Союзом) / Офіційний вебпортал Верховної Ради України. URL: https://zakon.rada.gov.ua/laws/card/c1237 (дата звернення: 08.01.2020).

17 Віце-прем’єр 3 питань євроінтеграції Дмитро Кулеба заявив, що Україна планує внести корективи в Угоду про асоціацію з СС : повідомлення агентства «Укрінформ-UATV» від 08 листопада 2019 p. URL: https://uatv.ua/ukrayina-planuye-vnestyzminy-do-ugody-pro-asotsiatsiyu-z-yes/ (дата звернення: 05.01.2020).

18 Матюшенко І.Ю., Беренда Л.І., Резніков В.В. Свроінтеграція України в системі міжнародної економічної інтеграції : навч. посіб. Харків, ХНУ ім. В.Н. Каразіна, 2015. С. 477.

\section{Резюме}

Передерій О.С. Тенденції трансформації законодавчих засад європейської інтеграції України на сучасному етапі.

У статті наводяться і розкриваються основні тенденції трансформації законодавчих засад європейської інтеграції України на сучасному етапі державотворення. Зокрема, аналізуючи проблематику імплементації Угоди про асоціацію між Україною і Свропейським Союзом, автор виокремлює три основні тенденції, які характерні для розвитку законодавчої основи політики європейської інтеграції: доповнення чинної Конституції України нормами про незворотність євроінтеграційного курсу, оновлення нормативних документів, які регламентують плановість процесу імплементації положень Угоди про асоціацію, внесення змін до чинної редакції Угоди про асоціацію.

Ключові слова: Україна, Свропейський Союз, європейська інтеграція, законодавство, Конституція України, Угода про асоціацію, правова система.

\section{Резюме}

Передерий А.С. Тенденции трансформации законодательных основ европейской интеграции Украины на современном этапе.

В статье освещаются и раскрываются основные тенденции трансформации законодательных основ европейской интеграции Украины на современном этапе государственного строительства. В частности, анализируя проблематику имплементации Соглашения об ассоциации между Украиной и Европейским Союзом, автор выделяет три основные тенденции развития законодательного поля для реализации политики европейской интеграции: дополнения действующей Конституции Украины нормами о необратимости евроинтеграционного курса, обновление нормативных документов, регламентирующих плановость процесса имплементации положений Соглашения об ассоциации, внесение изменений в действующую редакцию Соглашения об ассоциации.

Ключевые слова: Украина, Европейский Союз, европейская интеграция, законодательство, Конституция Украины, Соглашение об ассоциации, правовая система.

\section{Summary}

Oleksandr Perederii. Tendencies in the transformation of the legal foundations of European integration of Ukraine at the present stage.

The article presents and reveals the main tendencies of transformation of the legislative foundations of European integration of Ukraine at the present stage of state formation. While analyzing the problems of implementation of the Association Agreement between Ukraine and the European Union, the author highlights and reveals the content of three main tendencies that are characteristic for the development of the legislative basis of the European integration policy. In particular, the expanding of the current Constitution of Ukraine with the rules on the irreversibility of the European integration course, updating of normative documents regulating the planned character and gradual implementation of the provisions of the Association Agreement, amending the current version of the Association Agreement in order to update its provisions.

The attention is drawn to the fact that the modification of the legislative foundations of Ukraine's European integration course is an important political and legal factor for the transformation of not only the system of the legal system of the state in the formal sense, but also of the legal consciousness of the broad masses of the population. This is explained by the phenomenon of the action of socalled «future law». In practical terms, such a phenomenon manifests itself in the fact that in the society on the mental level there is an increasing level of expectations from the state to activate pro-European policy, further reforming of the national law in the direction of implementation of European models of social regulation. Accordingly, there is an impact on the minds of people by "future norms of law", which are designed to regulate social relations, which are just beginning to emerge.

Further priorities of expanding the legislative foundations of Ukraine's European integration are outlined. In particular, it is the optimization of the mechanism of substantial realization of European integration transformations in the practice of national state administration, as well as the preparation of legislative support to overcome the global political risks and economic threats that may occur in connection with the implementation of the Association Agreement. First of all, Ukraine should develop and accumulate the practice of applying the legislation in the sphere of increasing the investment attractiveness of Ukraine, guaranteeing the legal protection of foreign investments, adjusting the national manufacturing sector of Ukraine to the EU requirements, harmonizing the national model of legal regulation of the labor market with the EU, enhancing the institutional focus of the Ukrainian authorities to implement the EU Directives. system.

Key words: Ukraine, European Union, European integration, legislation, Constitution of Ukraine, Association Agreement, legal 